\title{
Erratum to : A New Era of Cartilage Repair using Cell Therapy and Tissue Engineering: Turning Current Clinical Limitations into New Ideas
}

\author{
Soon Hee Kim · Do Young Park · \\ Byoung-Hyun Min
}

Published online : 1 October 2012

(C) Springer-Verlag 2012

Corrigendum to : Tissue Engineering and Eegenerative

Medicine, Vol. 9, N0. 5, pp 240-248 (2012)

DOI 10.1007/s13770-012-0370-4

\begin{abstract}
A Corresponding author of the paper, Dr. Byoung-Hyun Min would like to add Acknowledgement "This research was supported by Fundamental Technology Development Project through the National Research Foundation of Korea (NRF) funded by the Ministry of Education, Science and Technology (MEST, 2011-0019730)" in the above feature article. The corresponding author wishes to convey sincere regret to the editor and readers of the journal of Tissue Eng.Regen.Med.
\end{abstract}

The online version of the original article can be found under DOI $10.1007 / \mathrm{s} 13770-012-0370-4$

Soon Hee Kim · Do Young Park · Byoung-Hyun Min

Cell Therapy Center, Ajou University School of Medicine, Suwon, 442-721 Korea 